\title{
血圧左右差に関する研究
}

\section{Study on the Difference of Blood Pressure Between Right and Left Arms}

\author{
新三菱重工(株)名古屋航空機製作所安全保健課 \\ 岩井淳 \\ Jun Iwai \\ Health and Insurance Section, Nagoya Air Craft Works, \\ Shin Mitsubishi Heavy-Industries, Limited
}

\begin{abstract}
A study on the differences of blood pressure between right and left arm has been performed for 364 workers who aged over 40 years old in a certain of Heavy Industry Plant, here in Nagoya.

The results were as follows:

1) No remarkable difference of blood pressure between right and left arm of these workers was observed, i.e. there was only 1.7 per cent of showing difference in systolic pressure more than $26 \mathrm{mmHg}$ (inclussive) between both arms, also 0.7 per cent for diastolic pressure.

2) Generally, persons who showed difference of blood pressure between both arms were higher in the right arms than left arms.

3) No correlation was found in the blood pressure between the grade difference of both arms and the girth of upper arms.

4) As a conclusion, it is recommended that the right arms rather left ones be bloodpressure-measured in order to select the hypertensive persons.
\end{abstract}

血圧について論ずるときは，まず血圧測定を正しく行 なうことが重要であることはいうまでもない。しかし血 圧值に及ぼす各種要因については種々検討されてきてい るにもかかわらず，尚不充分な点も少なくないと思われ る。血圧左右差についても，すでに Amsterdam \& Amsterdam $^{1)}$ をはじめ Beckmann ${ }^{2)}$, 武内 ${ }^{3)}$ 等, 松崎 ${ }^{4)}$ によ って報告されているが，職場における血圧管理の面か ら，スクリーニングに際し，左右いずれの上腕を測定す るのが妥当であるかに関しては，未だ問題点があるかと も考元られるので, この点を再検討し，併せて血圧と上 腕囲との関連について子考察を加えたので，その成績を 発表する。

\section{I 研 究 方 法}

\section{1. 対象及び測定時期}

名古屋市内一工場の 40 才以上の従業員で，秋季定期 健康診断時無作為に抽出した 364 名である。測定時期は 昭和 35 年 10 月で, 室温 $15 \sim 18^{\circ} \mathrm{C}$, 湿度は $30 \sim 70 \%$, 時刻は 9〜16 時の間に夫々実施した。

2. 測定方法

リバロッチ水銀血圧計を用い, 腰かけ位で膜型聴診器 による聴診法で実施した。左右上腕に同時に規定のマン
シェットをまき, 右から先に測定するものと左から先に 測定するものと交互になるようにした。

両上腕囲測定は両側血圧測定後, 両腕懸垂位において 計測した。尚，血圧值は末尾の数字を偶数として 0 ～8. までよみとることとした。

\section{II 研 究 成 績}

\section{1. 年令階級別左右別血圧度数分布}

被検者 364 名についての年令階級別左右別血圧分布は 図 1 に示すように, 最大血圧, 最小血圧ともに左右に著 しい分布差をみとめないが，最大血圧では 45４9才に， 最小血圧で 40４4 才にやや差があるので，この点を検 討するために, 同一人について左右差の度数分布をしら ベてみた。

\section{2. 年令階級別血圧左右差の分布}

左右血圧值の測定誤差を考虑して $6 \mathrm{mmHg}$ 未満を左 右差なしとし， $6 \mathrm{mmHg}$ 以上左右差を示すものを夫 右く左，又は右〉左とした。表 1 に示すように，血圧左 右差は最大血圧で $55.2 \%$ ，最小血圧で $42.5 \%$ を占め， 且つ最大血圧最小血圧いずれも右の方が左より高いもの の多いことを示した。符号検定を行なうと最大血压では 1\%の危険率で，最小血圧では $5 \%$ の危険率で夫々右の 
図 1 年令階級別左右別血圧分布

最大血圧” -...左腕人最八血圧
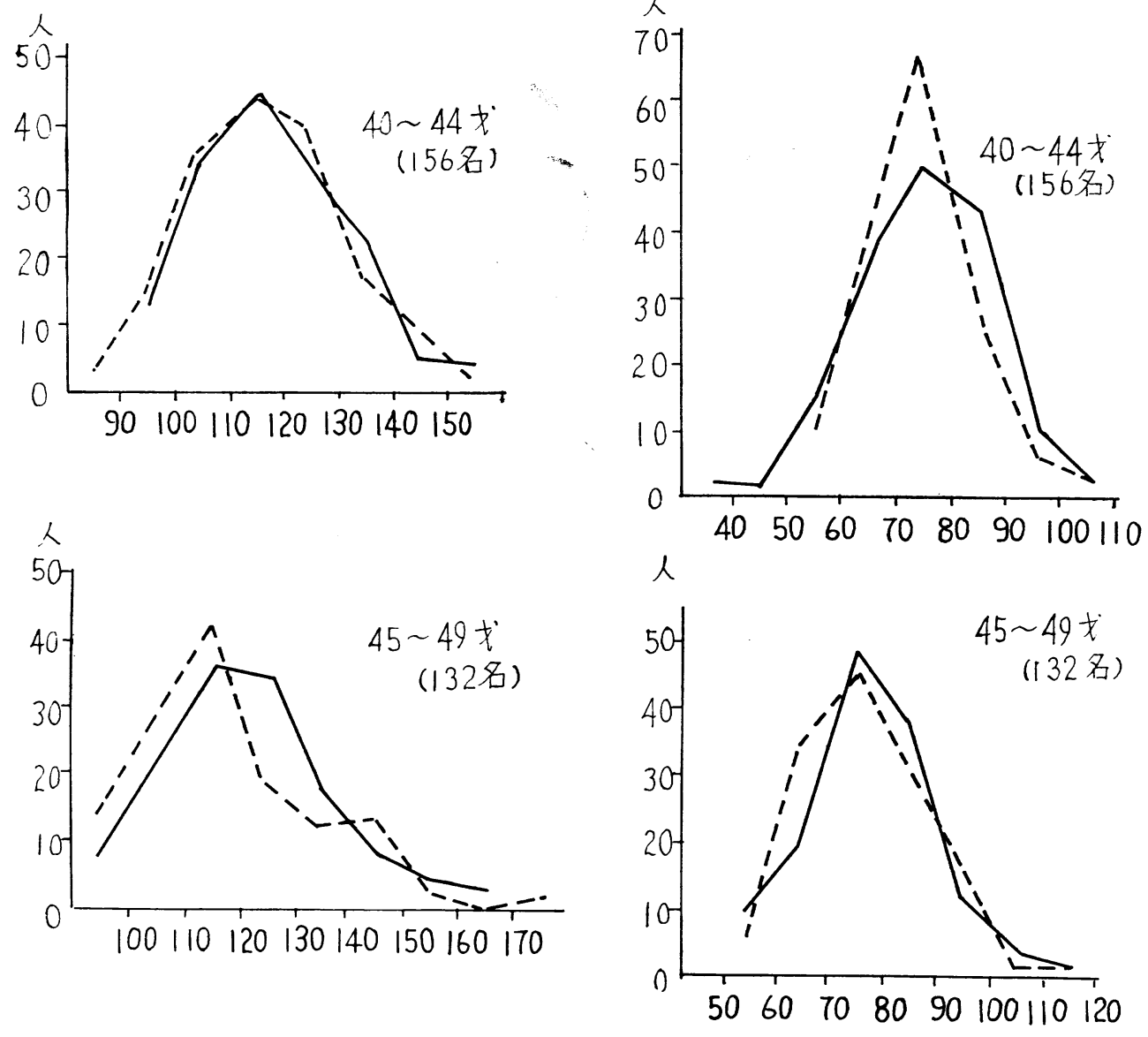

50 戈 $\sim$

(76名)
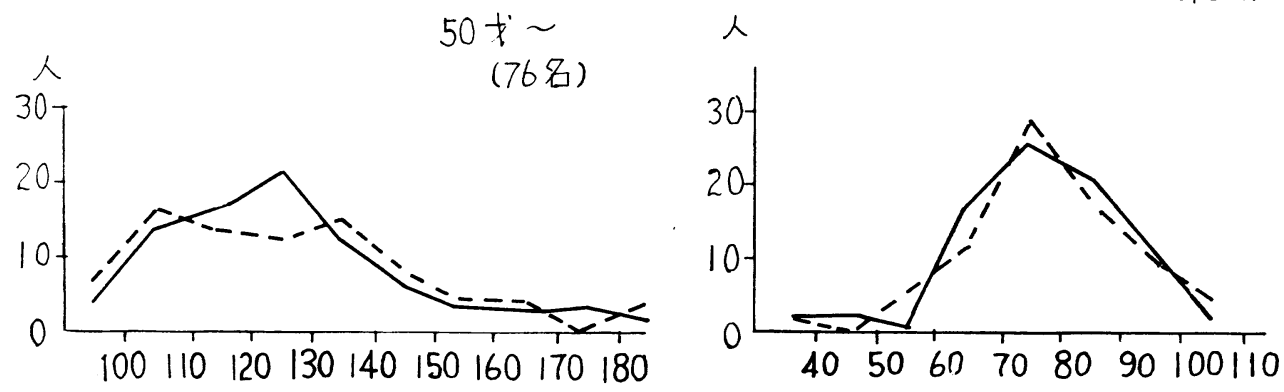
表 1 年令階級別血圧左右差

\begin{tabular}{|c|c|c|c|c|c|c|c|c|c|}
\hline \multicolumn{2}{|c|}{ 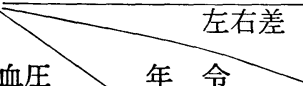 } & \multicolumn{2}{|c|}{ 右<左 } & \multicolumn{2}{|c|}{ 右 $=$ 左 } & \multicolumn{2}{|c|}{ 右>左 } & \multicolumn{2}{|c|}{ 計 } \\
\hline \multirow{4}{*}{$\begin{array}{l}\text { 最 } \\
\text { 大 } \\
\text { 血 } \\
\text { 压 }\end{array}$} & 40 〜4才 & 32 & (20.5) & 78 & $(50.0)$ & 46 & (29.5) & 156 & (100.0) \\
\hline & $45 \sim 49$ & 25 & (18.9) & 52 & (39.4) & 55 & (41.7) & $132 * *$ & $(100.0)$ \\
\hline & $50 \sim$ & 17 & $(22.4)$ & 33 & (43.4) & 26 & $(34.2)$ & 76 & $(100.0)$ \\
\hline & 計 & 74 & (20.4) & 163 & $(44.8)$ & 127 & $(34.8)$ & $364^{* *}$ & $(100.0)$ \\
\hline \multirow{4}{*}{$\begin{array}{l}\text { 最 } \\
\text { 小 } \\
\text { 血 } \\
\text { 圧 }\end{array}$} & 40〜44才 & 27 & (17.3) & 89 & $(57.0)$ & 40 & (25.7) & 156 & $(100.0)$ \\
\hline & $45 \sim 49$ & 23 & (17.4) & 79 & $(59.8)$ & 30 & $(22.8)$ & 132 & $(100.0)$ \\
\hline & $50 \sim$ & 15 & (19.7) & 41 & $(54.0)$ & 20 & $(26.3)$ & 76 & $(100.0)$ \\
\hline & 計 & 65 & (17.8) & 209 & (57.5) & 90 & $(24.7)$ & $364 *$ & $(100.0)$ \\
\hline
\end{tabular}

注） 1. ** $\mathrm{p}=0.01$ 危険率で有意 $* \mathrm{p}=0.05$ 危険率で有意

2. 左右差：右二左は $6 \mathrm{mmHg}$ 末満のものとした

表 2 年令階級別血圧左右差の分布

\begin{tabular}{|c|c|c|c|c|c|c|c|c|c|c|c|c|}
\hline & 左右差 & & & 大左 & & & & 右> & & & & \\
\hline & & $36 \sim$ & $26 \sim 35$ & $\hat{\partial} \sim 25$ & $\sim 15$ & & $6 \sim 15$ & $16 \sim 25$ & $26 \sim 35 \quad 36 \sim$ & 员 & & \\
\hline 最 & 40〜44才 & & & 6 & 26 & 78 & 41 & 4 & 1 & 156 & $+0.90 \pm 0.69$ & 1.304 \\
\hline 大 & $45 \sim 49$ & 1 & & 2 & 22 & 52 & 40 & 13 & 2 & 132 & $+3.18 \pm 0.90$ & $3.533^{* *}$ \\
\hline 血 & $50 \sim$ & & 1 & 4 & 12 & 33 & 21 & 4 & 1 & 76 & $+1.32 \pm 1.24$ & 1.060 \\
\hline 圧 & 計 & $\begin{array}{c}1 \\
(0.3) \\
\end{array}$ & $\begin{array}{c}1 \\
(0.3)\end{array}$ & $\begin{array}{l}12 \\
(3.3) \\
\end{array}$ & $\begin{array}{c}60 \\
(16.5) \\
\end{array}$ & $\begin{array}{r}163 \\
(44.8) \\
\end{array}$ & $\begin{array}{l}102 \\
(28.0) \\
\end{array}$ & $\begin{array}{c}21 \\
(5.7) \\
\end{array}$ & $\begin{array}{cc}3 & 1 \\
(0.8) & (0.3) \\
\end{array}$ & 364 & $+1.81 \pm 0.51$ & $3.549 * *$ \\
\hline 最 & 40〜44才 & & & 8 & 19 & 89 & 35 & 4 & 1 & 156 & $+0.71 \pm 0.66$ & 1.075 \\
\hline 小 & $45 \sim 49$ & & & 6 & 17 & 79 & 27 & 3 & & 132 & $+0.30 \pm 0.68$ & 0.441 \\
\hline 血 & $50 \sim$ & 1 & & 1 & 13 & 41 & 17 & 3 & & 76 & $+0.53 \pm 1.03$ & 0.515 \\
\hline 圧 & 計 & $\begin{array}{c}1 \\
(0.3)\end{array}$ & & $\begin{array}{c}15 \\
(4.1) \\
\end{array}$ & $\begin{array}{c}49 \\
(13.5) \\
\end{array}$ & $\begin{array}{r}209 \\
(57.4) \\
\end{array}$ & $\begin{array}{c}79 \\
(21.7) \\
\end{array}$ & $\begin{array}{c}10 \\
(2.7)\end{array}$ & $\begin{array}{c}1 \\
(0.3)\end{array}$ & 364 & $+0.52 \pm 0.44$ & 1.181 \\
\hline
\end{tabular}

注） $1 . * * \mathrm{p}=0.01$ 危険率で有意

2. 差の平均値は右>左を十とした

高いものが左の高いものより多く, 特に最大血圧 45〜 49 才階級に有意にみとめられた。

更にこの左右差の度数分布をつくってみると, 表 2 に みるように $26 \mathrm{mmHg}$ 以上の左右差を示するのが, 最大 血圧で 6 名 $1.7 \%$, 最小血圧で 2 名 $0.6 \%, 16 \mathrm{mmHg}$ 以上の左右差を示すものが夫々 39 名, $10.7 \%$ 及び 27 名 $7.4 \%$ にみとめられた。又, 右く左を一, 右>左を十 として左右差の平均值を求めると, 最大血圧, 最小血圧 について各年令とも+となり, 右が左より高いことを示 乙， $t$ 検定を行なった結果，最大血圧殊にその 45〜 49 才に $1 \%$ の危険率で有意差をみとめた。最小血圧では同 様の傾向はあったが，有意差はみられなかった。

3. 測定順位別血圧左右差

右から先に測定した場合と, 左から先に測定した場合
とで差があるかどうかを検討した。対象のうち測定順位 の明らかでないものが一部あったので，これらを除いた 312 名についてやはり左右差 $6 \mathrm{mmHg}$ 未満を左右差な しとし右＜左及び右＞左のものの割合を右から先に測定 したものと左から先に測定したものとで比較してみると 表 3 のと打りであって, 最大血圧最小血圧ともに $\chi^{2}$ 試 験の結果いずれも有意差は全くなく，左右いずれから測 っても差はないことを示した。

4. 血圧值と血圧左右差との関倸

最大血圧 140 , 最小血圧 90 を境として，夫々血圧の 高い群と低い群とにわけて，血圧左右差を比較してみる と, 表 4 亿示すように最大血圧最小血圧ともに全く左右 差はみとめられず，血圧の高い群に左右差が著しいとい うことはなかった。 
表 3 測定順位血圧左右差

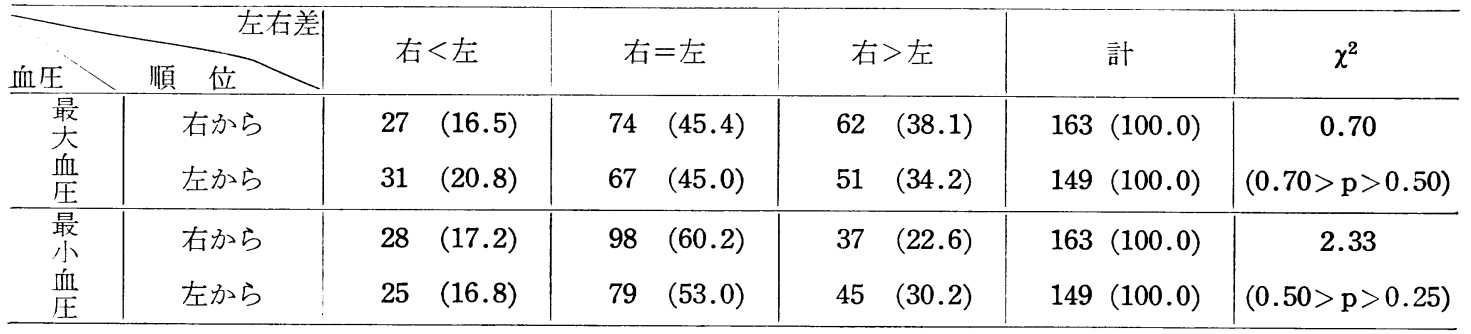

注）右=左： $6 \mathrm{mmHg}$ 未満のものとした

表 4 血圧値別血圧左右差

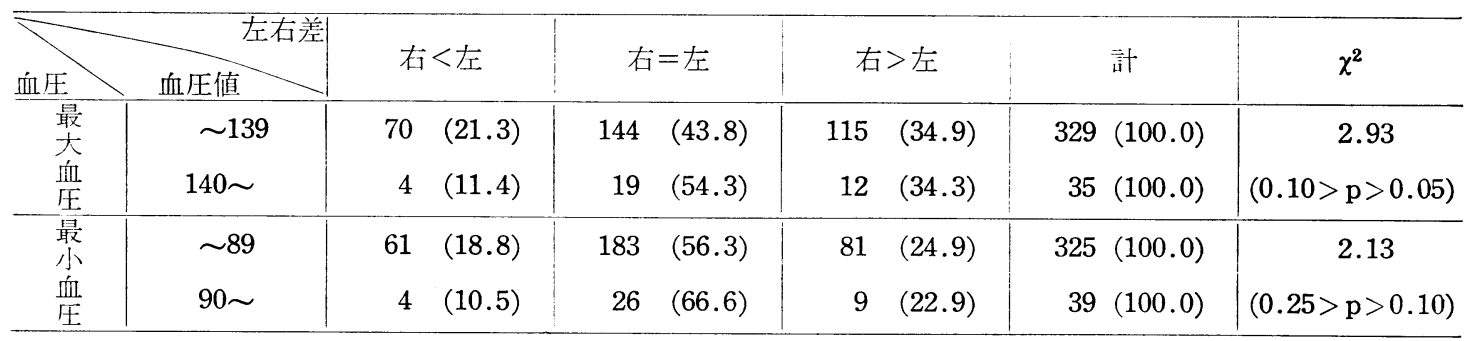

表 5 血圧值亡上腕囲（右腕）との関係

\begin{tabular}{|c|c|c|c|c|c|c|c|c|c|c|}
\hline z & 血圧值 & \multicolumn{2}{|c|}{ 細 } & 普 & 通 & \multicolumn{2}{|c|}{ 太 } & \multicolumn{2}{|r|}{ 計 } & $\chi^{2}$ \\
\hline 最 & $\sim 139$ & 17 & $(5.3)$ & 292 & (88.6) & 20 & (6.1) & 329 & $(100.0)$ & $6.02 *$ \\
\hline $\begin{array}{l}\text { 血 } \\
\text { 圧 }\end{array}$ & $140 \sim$ & 1 & $(2.8)$ & 28 & $(80.0)$ & 6 & $(17.2)$ & 35 & $(100.0)$ & $(0.05>\mathrm{p}>0.01)$ \\
\hline 最 & $\sim 89$ & 17 & $(5.2)$ & 288 & (88.6) & 20 & $(6.2)$ & 325 & $(100.0)$ & 5.20 \\
\hline 血 & $90 \sim$ & 1 & $(2.5)$ & 32 & $(82.1)$ & 6 & (15.4) & 39 & $(100.0)$ & $(0.10>p>0.05)$ \\
\hline
\end{tabular}

注）1.上腕囲 細： $21 \mathrm{~cm}$ 未満, 普通： $21 \mathrm{~cm}$ 以上 $28 \mathrm{~cm}$ 未満, 太： $28 \mathrm{~cm}$ 以上

2. * $\mathrm{p}=0.05$ 危険率で有意

表 6 血圧左右差と上腕囲左右差との関係

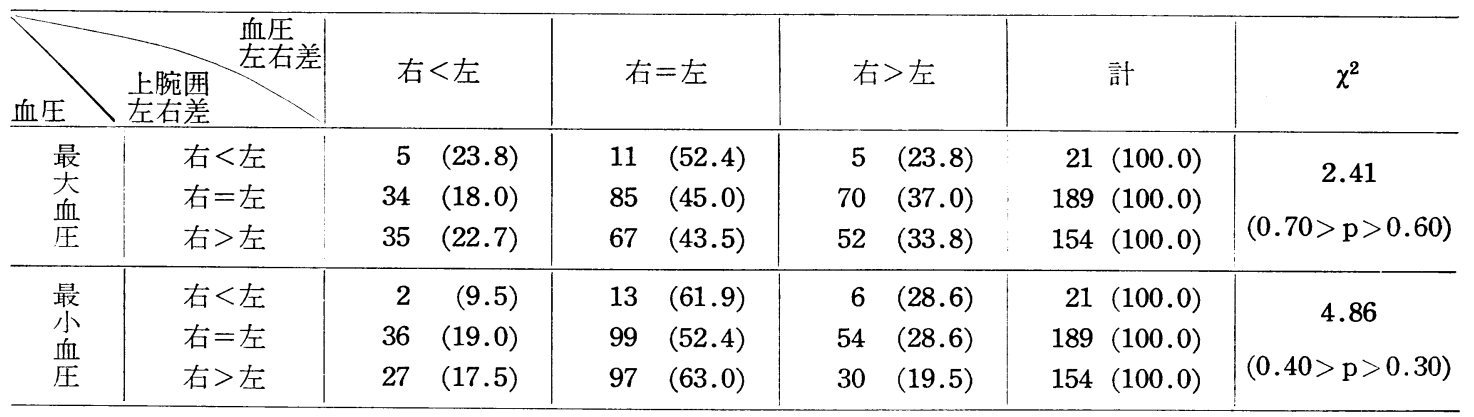

注）血圧左右差：右二左 $6 \mathrm{mmHg}$ 末満のものとした

上腕囲左右差：右二左 $0.6 \mathrm{~cm}$ 未満のものとした 
5. 血圧值と上腕囲（右腕）との関係

上腕囲は右腕を測定し $21 \mathrm{~cm}$ 以上 $28 \mathrm{~cm}$ 末満のもの を普通とし, $21 \mathrm{~cm}$ 末満を細, $28 \mathrm{~cm}$ 以上を太とすること にし, 最大血圧, 最小血圧ともに前項のように血圧の高 い群と低い群とにわけて比較した。表 5 の如く最大血圧 においては血圧の高い群に腕の太いものが多く $17.2 \%$ を占め, 血圧の低い群に腕の細いものが多く $5.3 \%$ 示 し，これは $\chi^{2}$ 試験の結果 $5 \%$ の危険率で有意差であっ た。しかし, 最小血圧においては, 同様の傾向がみられ はしたが，5\% の危険率で有意の差はみとめられなかっ た。

\section{6. 血圧左右差と上腕囲左右差との関係}

上腕囲左右差は利き腕との関係を示すのではないかと 考えて, $0.6 \mathrm{~cm}$ 末満のものは上腕囲左右差なしとし, $0.6 \mathrm{~cm}$ 以上差のある場合を, 右 $>$ 左又は, 左 $>$ 右とし た。血圧左右差と上腕囲左右差との間には表 6 のとおり 最大血圧最小血圧のいずれにおいてもほとんど関係はみ られなかった。

\section{III 考按}

血圧左右差に関してはすでに二, 三の報告がみられ， そのいずれもが健常人においても，かなりの左右差のあ ることを認めている。しかも右の方が左より高い傾向の あることを指摘するものが多い。

集団検診におけるスクリーニングとして血圧測定を実 施する場合, 血圧異常者であるにかかわらず健康者とし てふるいおとしてしまう確率, false negative rate $(\beta$ 第 2 種の過誤）をできるだけ最小にしょうとするために は，すこしでも血圧の高い疑いがあるものをできるだけ ふるいあげることであって，そのためには血圧值の高い 方の上腕を測定する必要があるといえよう。ただこのた めに健康者であるにかかわらず異常者として判断されて しまう確率, false positive rate ( $\alpha$ 第 1 種の過誤) が大 きくなる可能性があるが，この $\alpha$ と $\beta$ との和が最小とな るようにするための条件を決定することは，高血圧管理 上今尚充分には究明されていない。

本報告はこれらの点の解決に一つの示唆を与えるむの として, 改めて血圧左右差についての検討を加えてみる ことにしたものである。

左右両上腕の血圧を正確に同時に測定する事は極めて 困難であり，Beckmann ${ }^{2)}$ が行なったように，両上腕に 装着したマンシェットを一つのゴム球で同時に送気でき るような装置を使用するのが最も正確であろうが，本研 究では両側にマンシェットを同時にまき, 右から先に測
定するものと左から先に測定するものと交互になるよう にし，同一血圧計で同一人が測定することとした。特に 安静時間をとらせなかったが, 血圧左右差の分布にはい ずれから先に測定しても殆んど差はみられなかった。又 それぞれ 1 回のみの測定值であったが，反復測定して安 定した血圧值を以って左右比較する方がより正確である うと思われた。

左右差 $6 \mathrm{mmHg}$ 末満を差なしとすると，最大血圧で は $55.2 \%$ ，最小血圧では $42.5 \%$ に左右差をみとめたわ けであるが，Beckmann ${ }^{2)}$ の夫々 $60.0 \%$ 及び $42.0 \%$ に 左右差をみとめたのと殆えど一致した值である。上田, 武内 ${ }^{3)}$ は健常群においては夫々 $87.0 \%$ 及び $76.0 \%$ に みとめているが，これは左右 $1 \mathrm{mmHg}$ 以上差のあった 場合すべてを含んでいるので直ちに比較はできない。

左右差の程度をみると, $26 \mathrm{mmHg}$ 以上の明らかに差 を示すものが最大血圧で $1.7 \%$, 最小血圧で $0.6 \%, 16$ $\mathrm{mmHg}$ 以上の左右差を示すものが夫々 $10.7 \%$ 及び $7.4 \%$ であった。Beckmann ${ }^{2)}$ の $10 \mathrm{mmHg}$ 以上左右差 を示すものが夫々 $31.0 \%$ 及び $10.3 \%$ という值, 或い は上田, 武内 ${ }^{3)}$ の $11 \mathrm{mmHg}$ 以上左右差を示すもの夫ヶ $16.0 \%$ 及び $17.0 \%$ という值と比較してみると大体の傾 向は同様と考えることができる。

又, 左右差は右〉左の方が左〉右より多く特に最大血 圧の方に著しく, 最小血圧ではそれほど著明ではない。 この点諸報告も殆えど同様の成績である。

一方, 血圧值から血圧左右差を眺めると, 本研究では $\mathrm{Beckmann}^{2)}$, 上田, 武内 ${ }^{3)}$ のいう如く健常群之高血圧群 とでは差はないようであったが, Amsterdam \& Amster$\mathrm{dam}^{1)}$ によると高血圧患者では左右差は著しくなり且血 圧值の高い程左右差も大となる傾向があるといい，松 崎) も自衛隊員について正常群に比し高血圧群では 10 $\mathrm{mmHg}$ 以上の異常左右差の発現がはるかに大きいとい っている。

利き腕と血圧左右差との関係については Amsterdam \& Amsterdam $^{1)}$, Beckmann $^{2)}$ が左利きのものでも右が 高いものの多いことを示しており, 利き腕の方の血圧が 高いとはいえないようである。本研究では上腕囲の左右 差と血圧左右差との関係をみたのであるが，最大血圧， 最小血圧ともに殆えど関係はみられなかった。

健康人に血圧左右差がかなり認められしかも右の方が 左より高いという理由については多くの解釈が下されて いるが，今回の成績からみても測定の順位，利き腕とは まず関係はないように思われる。血圧值との間に㵔し い関倸は認めなかったが，血圧が高くなればそれだけ左 


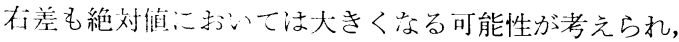
两に例数を增こての検討召必要かと思われる。Burch \& De Pasquale ${ }^{5}$ はかかる血压左右差は一時的なものであ り，且変動し易いものだあるとし，特に大動脈弓疾患の 骖断には意味があるといっている。Amsterdam \& Amsterdam $^{1 ;}$ :この血左左右差を大動脈及びその分枝 の解剖学的関係によるものといい, Beckmann ${ }^{2}$ 注最大 血王の左右差汇上腕血管の弾力性が中枢性，末梢性に高 まるためであり，最小血圧の左右差は主として末㮐抵抗 の差に基づくものだあるという。しかし著しい左右差を 認めた場合は, 一応, 血管, 心臓, 中枢神経系の各疾患 艺疑ってみることは必要なことであろう。

集団検診において血圧測定により血压異常者をふるい 分けるためには，左右上腕のいずれをえらぶかは，かか る点から考えると，必ずしも高い側を測定すれ柾足りる と簡単にいいきるわけにもいかない。の天゙ましいのは両 側党に測定し，いずれか高い值を示す側茎確認してふ るいわけることであろう。しかし，実際に左右差を示す 場合をみると, 右>左が左>右よりもはるかに多い点か ら考えて，一方のみを測定する限り右腕を測定するのが 血压異常者発見のためには妥当といい得る。左上腕で高 血圧を示すが右上腕では正常血圧というものがスクリー ニング洩れとなる可能性を更に検討して，いふ沉これを 最小にするかが今後の問題であるう。

\section{IV 結 論}

高血压集団検骖に際し，左右いずれの上腕を測定する のがスクリーニングとして妥当であるかを40才以上の 一工場従業員 364 名について，血左左有差小ら検討し， 上腕囲との関連から次のような成績を得た。

(1) 血压左右差证, 最大血压に拈いて $55.2 \%$, 最小 血压において $42.5 \%$ こみられ，26 mmHg 以上の差它 示与もの分，夫↔ $1.7 \%$ 及び $0.6 \%$ にみられた。
(2) 血压左右差は右〉左の方方左〉有に比して多くみ られ，特に最大血压において著しい。

(3) 右から先に測った場合上左から先に測った場台之 では左右差には差をみとめなかった。

(4) 血圧左右差と血压值との間には，血压の高以群に 左右差が著しいということとはなかった。

(5) 血圧值と上腕囲との間には最大血在の高い群に腕 の太いものがみら机たが，最小血圧では著明ではなかっ た。

(6) 上腕囲左右差と血压左右差との間にはほとんど関 係はなかった。

(7) 以上, 高血压スクリーニングとしては右が左より 高い值を示すものが多いことから考えて, 左上腕よりも 右上腕を測定するのが異常者発見には妥当ではないかと 思われる。

終わりに臨み御校閲を頂いた岡田博教授並びに協力を 惜しまれなかった名古屋大学医学部予防医学教室員各位 及び当新三菱重工 (株) 保健婦諸姉に感謝します。

本論文の要旨は第 32 回日本衛生学会総会（昭和 37 年 4 月）において発表した。

\section{文献}

1) Amsterdam and Amsterdam: New York State J. Med., 43；2294，1943（上田, 武内：高血圧症よ り引用)

2) Beckmann, A.: Dtsch. med. Wschr., 78; 218, 1953

3）上田英雄, 武田重五郎：高血圧症, 診断之治療, 医 菌薬出版, 東京, 昭 35

4) 松崎俊彦：日本衛生学雑誌，15；18，昭 35

5) Burch, G. and De Pasquale, N. P.: Primer of Clinical Measurement of Blood Pressure, C. V. Mosby Co., St. Louis, 1962 